\title{
Internationalization of Bangladeshi Banks: What Can We Learn?
}

\author{
Tasneema Khan, Bipasha Barua* \\ Lecturer, Department of Banking and Insurance, University of Dhaka, BANGLADESH \\ *E-mail for correspondence: bipashabarua18@gmail.com
}

Received: Dec 29, 2016;

Accepted: Mar 31, 2017;

Published: May 13, 2017

Source of Support: Nil

No Conflict of Interest: Declared

\begin{abstract}
Internationalization of banking institutions has been more evident to a greater extent recently due to the advancement of technology and global inter-connectedness. As the 'engine of economic growth,' banks are the dominant players in Bangladesh financial market. Due to intense competition and quick saturation of the domestic market, banks in Bangladesh are tending to move towards the international market. This research aims to explore the nature and challenges of international banking practices in Bangladesh banking sector, and also to develop the relevant policy perspectives. A semi-structured questionnaire was used to survey top level management of 41 out of total 56 scheduled banks operating in Bangladesh during May 2015. Analyzing the survey, the study finds that Bangladeshi banks do not follow the usual internationalization path, tends to more cost-intensive mode, are in the defensive approach of internationalization, and face several challenges and deficiencies in their current international banking practices. This paper contributes to existing literature by being the first exploring the facet of bank internationalization in Bangladesh and generating new insights for better bank regulation.
\end{abstract}

Keywords: Internationalization, Degree of Internationalization, International Banking, Profitability, International Entry, International Expansion

JEL Classification: M16, M20, N20, F23, G20, L10

\section{INTRODUCTION}

Globalization and advanced technology have accelerated the delivery of banking products and services from one country to another in a far easier way. The wider interconnectedness has broadened the scope of operation for banks that create growth opportunity and tap the untapped. Following the global banking trend, these factors have motivated Bangladeshi banks to provide international products and services staying at home or going abroad. International business activities by Bangladeshi firms have increased considerably mainly because: entrepreneurs are increasing their international business and importantly, and migration and export of Bangladeshi citizens have been increasing globally. The banking sector in Bangladesh is facing its fourth generation wave currently and, furthering foreign market expansion for better growth and business opportunity is considered a promising strategy by Bangladeshi banks. In these circumstances, it has become now quite relevant to understand how banks in Bangladesh are dealing with the international banking issues in practice.
This study is aimed to examine the degree and nature of internationalization of Bangladeshi Banks and challenges underlying in advancing international linkages and to inquire the policy perspectives of the Banks on internationalization. This study is going to contribute to the existing research and literature in few very important ways: (i) this research is going to be a first-hand contribution on internationalization of Banks in Bangladesh, (ii) this research examines internationalization with a wider approach using different dimensions compared to existing studies, and (iii) this study offers new but critical observation on the importance of regulation related to international banking practices in Bangladesh.

\section{REVIEW OF LiTERATURE}

When a commercial bank operates cross-border and cross-currency banking transaction, it is known as Internationalization. Some literature measure internationalization based on the availability of presence of banks in foreign countries, but a broader conceptual definition involves all ranges and ways how a bank delivers international banking products and services to 
domestic or international clients either staying at home or reaching out into foreign countries (Trivedi, 2012). This chapter reviews the literature on internationalization of banks including its determinants, modes of international exposure and theoretical underpinning behind internationalization.

Internationalization decision by banks is triggered by some factors. Among those innovations in financial product, saturated domestic market, regulatory reforms, information technology advancement, globalization trend of international trade are found to be crucial. Hollensen (2008) identified two sets of reasons of internationalization of a company: (i) Proactive - Profit and growth goals, Technology competence, Economies of scale; Cost reduction, Foreign market opportunities, Managerial urge, Access to resources, and (ii) Reactive Competitive pressures in the domestic market, Domestic market small and saturated, Lowering sales, Overproduction, Unsolicited foreign market orders, Extend sales of seasonal products, Proximity to international customers, and Psychological distance.

A study shows that foreign market entry was initiated by some firm-specific factors such as adequacy of the institution's capital base, the institutional risk base, and technology base, quality of human resources, information and market accessibility, management culture, quality of entrepreneurship (Porter, 1985; Canals, 1997; Smith and Walter, 1997). Again some macro and industry related factors such as the success of banking sector reforms, a shift in the strategic scope of the banks and a desire to exploit tangible and intangible assets in less developed but profitable banking markets are recommended as essential aspects for exploiting the opportunities of internationalization (Amungo, 2014). Yuliya and Adela (2012) hinted following customers, increasing market power and high profitability as incentives of internationalization. Although during financial crises banks may be negatively affected by international expansion (Berger et al., 2015). Tripe (2003) marked profitability as the significant reason behind international expansion whereas Canals (1997) argued customer service and resource transfer as the main incentives for international activity. Another study by Rahman and Anuar, (2011) found that "following the domestic clients" and "market seeking motives" work as the driving forces of international expansion. This result is also consistent with Lensink and Hermes (2004) who identified following the clients (defensive expansion), attractiveness of the host markets, imitation of competitors, reduction of capital cost, and risk diversification as the motivations for internationalization of banks.

To go international, a bank can choose among several modes of entry (Trivedi, 2012). Considering the level of control, a firm seeks a number of resources it is ready to commit and the level of risk it is willing to take a firm makes the entry mode choice to foreign market (Amungo,
2014). Smith and Walter (1997) identified a threedimensional matrix of "Client -Arena-Product" (CAP) framework as the more structured approach used by banks for developing strategies of internationalization. Among various modes available for bank internationalization, Slager (2005) identified two major modes in organizational forms that are branch network, and alliances and joint ventures. Whereas Teschoegl (2001) stated that agencies, branches, representative offices, and subsidiaries are mostly used as the mode of internationalization by banks. Interestingly, Ceruttiet et al. (2007) reveal that branch is more striking choice compared to subsidiaries due to avoidance of higher corporate tax, easy profit and greater market opportunity in poor countries. Yuliya and Adela (2012) stated that acquisition is the most identical mode of entry choice for banks with experience and knowledge about the new market. Buch et al. (2011) stated that both branches and subsidiaries are highly cost-intensive. In contrast, correspondent banking allows delivery banking services without physical presence abroad is (Khoury, 1998).

However, internationalization may have significant impacts on bank performance, and this has been studied by some studies, although the findings are non-conclusive. As Sullivan (1994) reported on seventy studies that six of them revealed positive, five negative and remaining six found no relationship between different internationalization indicators and financial performance of banks. Negative impact on financial performance essentially is serious concern for banks and may arise for different reasons for example choosing inappropriate destination, lack of appropriate strategy, high risk and competition, lack of human resources etc. Internationalization doesn't contribute much to profitability and hence opportunity for shareholders benefit is limited (Slager, 2005; Buch et al., 2011). Antonsson and Arrhenius (2011) found very low rating with need for "little supervision" on two large internationalized banks they studied. In addition, there is also literature suggesting benefits of internationalization for example, through geographical diversification resulting in better risk-return trade-off (Berger et al., 2000; Goldberg, 2001; Buchet al., 2010). Moreover, internationalization help banks to improve domestic performance using the international experience effectively (Kobrin, 1991).

There have been a number of studies on the banking sector of Bangladesh. Much of the focus of those has been on the performance issues of banks with different aspect, status and management of NPL, implementation and growth of e-banking etc. But after an extensive search, we find no study, so far, focused on internationalization of banks in Bangladesh even though the banks here are no longer confined to domestic operation anymore. This study mainly focuses on international exposure of banking institutions currently operating in Bangladesh. 


\section{Data AND Methodology}

To explore the nature and dynamics of international banking activities performed by Bangladeshi banks, and related challenges and policy issues, a descriptive method with tabular analysis has been applied to a detailed set of survey data. The detail on these follows.

\section{Sample and Data}

Among the total 56 scheduled banks operating in Bangladesh, nine foreign commercial banks have been excluded to comply with the objective of study. Specialized banks are excluded because those were established to serve domestic market for development purpose. However, one of the Specialized Banks is included as its nature of services is similar to commercial banking and also just to explore how they see the internationalization issue. Moreover, out of total 9, 5 completely new commercial banks have been excluded due to their very limited age of business and remaining 4 new banks are included. Therefore, finally a total of 41 scheduled banks including 34 Private Commercial Banks (26 Traditional plus 8 Islamic), 6 Sate-owned Commercial Banks, and 1 Specialized Bank have been surveyed and studied. To acquire required data and information, a 6 page detailed questionnaire was administered to survey the 41 scheduled banks operating in Bangladesh physically in May, 2015.

\section{ANALYSIS, RESULTS AND Discussions \\ Exposure and Outreach of Foreign Operation}

The analysis shows that around $90 \%$ of the banks surveyed had some forms of international operation. The forms of international operation largely range from merely having foreign trade product to investment or lending in other countries to establishing subsidiaries. Figure-1 shows that a total of 37 out of 41 banks surveyed had some forms of international operation.

Figure 1: Country Exposure of Banks

\section{Existing International Operation Destination}

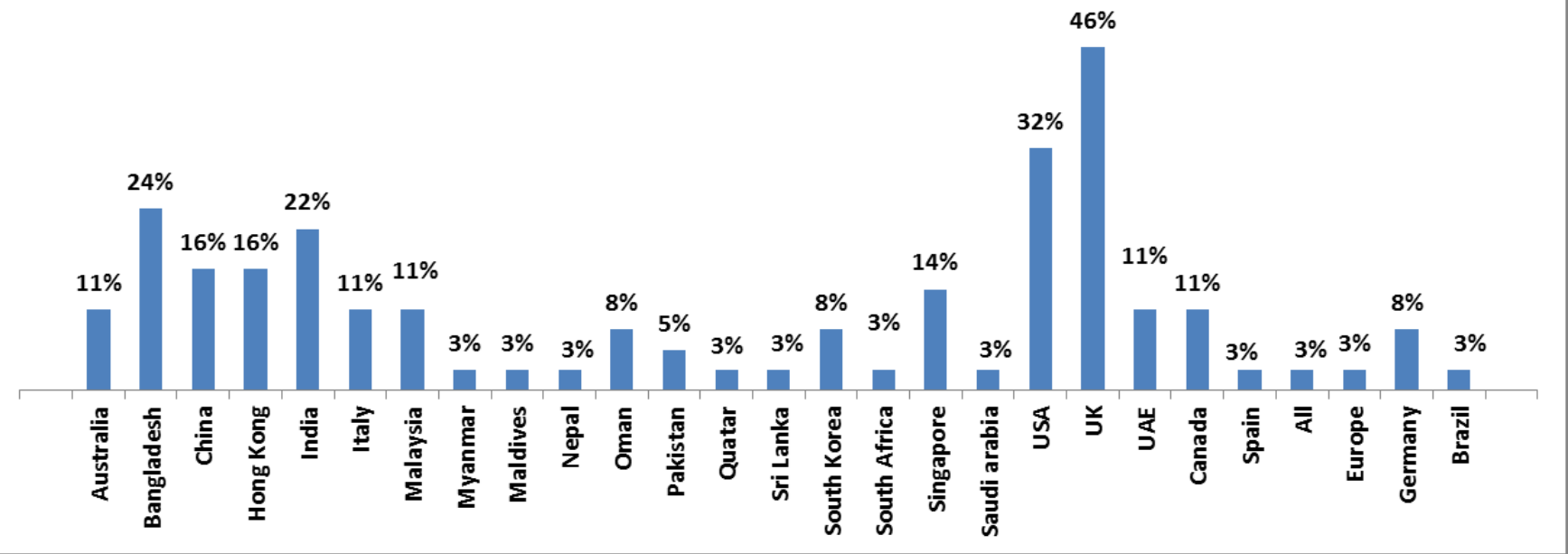

Source: Developed by authors based on survey data.

Results show (Figure-1) that $46 \%$ of the banks have products, services or operations with the United Kingdom and $32 \%$ has with the United States. This might be the existence of a large number of Bangladeshis for a long time in those two countries. It is also notable that, $22 \%$ banks have links with India which is quite less than expected since Bangladesh has a very large volume of business between the two countries. However, countries like Malaysia, Saudi Arabia are the top destinations.

\section{Forms and Types of International Banking Operation}

Banks reported that they largely offer Money Exchange services through their international operation either from home or physical operation abroad. About $76 \%$ of the banks reported they offer money exchange while around $60 \%$ offer Wholesale Banking products and services such as Export-Import facilitation, trade financing etc. Of course, 51\% offer Retail services also such as regular deposit and lending. Merely, 11\% deliver Capital Market related products and services such as securities investment through their international operation window.

Figure 2(a): Types of Products and Services

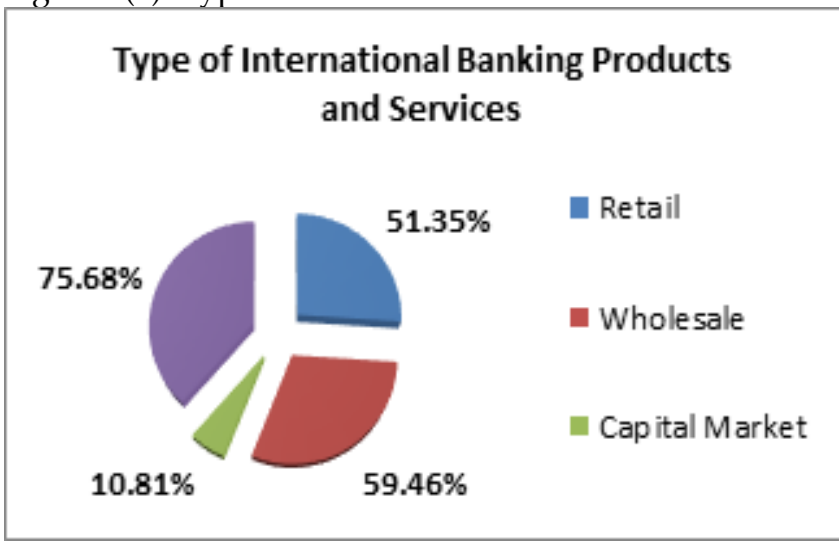


Figure 2(b): Modes of Entry and Linkage

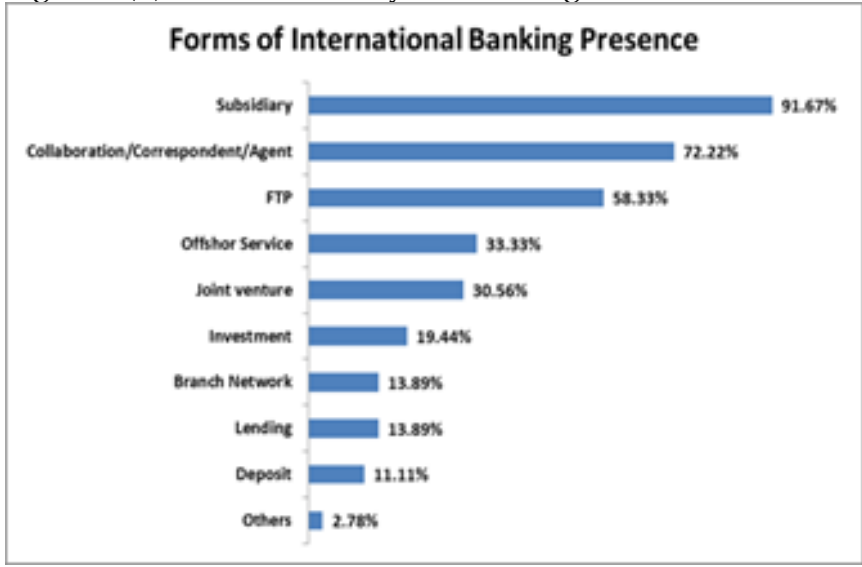

Source: Developed by authors based on survey data.

Interestingly, as Figure 2-b shows most banks reported that they had subsidiary operations for international markets although it is highly cost-intensive. Subsidiaries are usually established by Bangladeshi banks in other countries to cater larger markets. Around $92 \%$ of the banks have subsidiaries outside the country while $72 \%$ have arrangements with foreign banks. Such collaborative arrangements mean foreign banks act as Correspondent or Agent of Bangladeshi banks in other countries. About $59 \%$ have foreign trade products such as trade financing, LC arrangement etc. that are delivered from offices inside Bangladesh. It is found that only 33\% reported that they have offshore banking division and services. It means around $26 \%$ of the banks deliver foreign trade products and services without having offshore division or services from their operation inside Bangladesh. Figure- 3 shows a Layer of Internationalization or Internationalization Path using the forms of internationalization reported in Figure2(b). A total of 7 Layers has been constructed based on the 9 forms explained above which essentially indicates the degree of internationalization based on greater coverage of, arrangements with and without physical existence in the outer world. The degree definition of the layers is done based on the extent banks are financially committed and exposed with fixed investment.

Figure 3: Layers of Internationalization

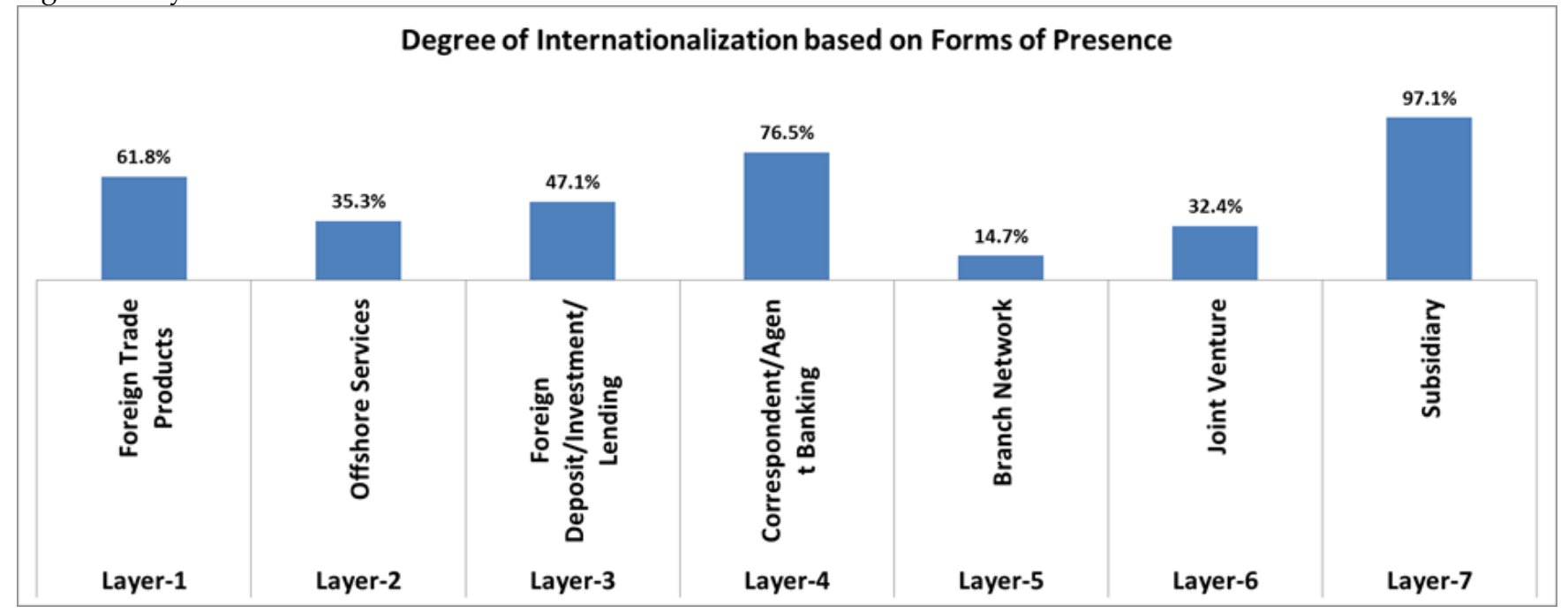

Source: Developed by authors based on survey data.

The layer-wise internationalization data shows a scattered pattern. Although it is expected that number of banks doing business internationally at higher layers will be lower compared to the lower levels having higher number of banks participating. This is because of larger amount of firm investment, management ability, and highest level preparedness to compete at the global level at the higher levels such as having Subsidiary, Joint Venture or Branch Network compared simply offering foreign trade products, offshore services staying at home.

It is found that most banks reported that they have subsidiaries outside Bangladesh to deliver international banking products and services. Around 97\% of the banks who said positively to the question of having international banking have the highest level of internationalization possible which is fairly unexpected although might show a growing interest for aggressive internationalization. Compared to the finding on Subsidiary, $62 \%$ of the banks have foreign trade products and $35 \%$ have offshore services which seem to be surprising as offering foreign trade product and offshore services should be considered as the basic beginning of internationalization for a bank. In this context, finding a substantial $32 \%$ of the banks having joint venture investments internationally is also quite a matter of demand for sign of aggressiveness as this also involve a greater investment commitment, global competition ability, and higher management ability in overseas market.

The response rate for foreign investment/lending/ deposit $(47 \%)$ is quite expected at this age of banking sector in Bangladesh. Collaborations such as Agent 
Banking and Correspondent Banking are always very popular modes for banks who want to avoid large physical investment and greater financial risks but want to achieve a global network for a range of products and services. This finding is also evident from Bangladeshi Banks where as much as $77 \%$ of the Banks have collaborations worldwide with foreign banks through which they deliver all possible international banking operations permitted by Bangladesh Bank rules and regulations. Going above the collaboration (layer-4) involves physical existence in outer world that require substantial investment and financial commitment, and much greater complexity and risk. Despite this fact, number of banks having Joint Venture and Subsidiary is highly significant as explained earlier but pretty confusing to see that Branch network is created by only $14 \%$ of the banks although it is relatively cheaper or less cost-intensive mode.

Figure 4: Age of Internationalization and Number of Banks at Different Layers

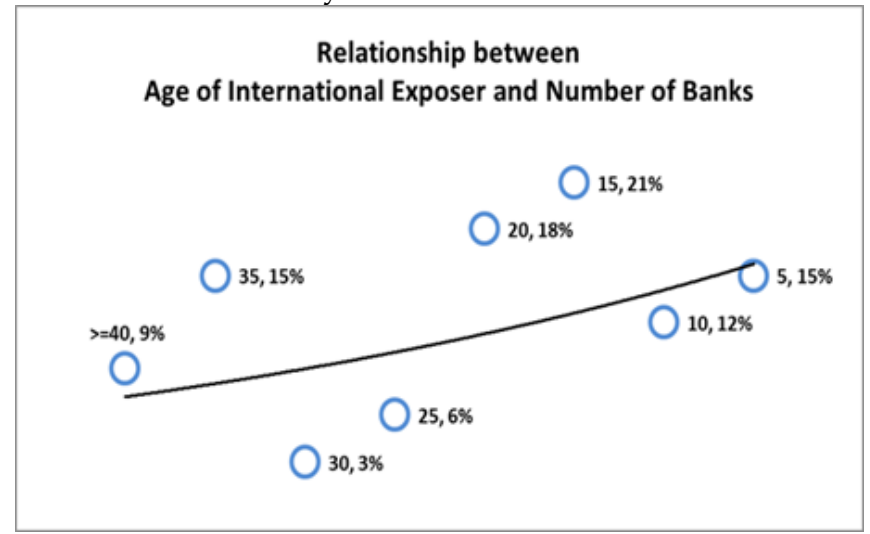

Source: Developed by authors based on survey data.

There is better insight when we look at the number of banks in different layers of internationalization in relation to the age of serving with international products and operation. Figure-4 shows a clearly positive relationship. This indicates that banks with introducing international products, services or operation in recent times are more and the number of banks offering such services and operation is increasing over time. As we can see from Figure- 4 , around $30 \%$ of the banks surveyed have such experience of less or equal to 15 years where the period after 2000 is termed as "Third Generation" for banking sector while around $27 \%$ have experience of greater than or equal to 25 years (before 1990s, it is termed as First Generation) (Haque, 2013; Islam, 2010).

\section{Incentives for Internationalization}

Why did the banks go international? About $97 \%$ of the banks reported that increasing customer pool and high business and profit opportunity have motivated them largely for introducing international products or operation. Most banks (roughly 50\%) rated these two reasons giving higher level of motivation. However a total of $92 \%$ and $81 \%$ also reported the motivation to diversify their business risk and product portfolio although mostly reported these two factors as moderately motivating on average. Of course, another crucial incentive is the existence of Non-Resident Bangladeshis (NRBs) in different countries worldwide which has been cited by around $83 \%$ of the banks mostly rating this as high motivational factor. Although, as expected about $72 \%$ banks regarded mature domestic market is a key concern as too many banks and other financial institutions are already chasing too few customers.

Table 1: Incentives/Motivations for Going International

\begin{tabular}{|l|r|r|r|r|r|c|}
\hline & \multicolumn{5}{|c|}{$\begin{array}{c}\text { Degree of Importance } \\
\text { (Figures in \% Banks) }\end{array}$} \\
\hline \multicolumn{1}{|c|}{ Incentives/Motivations } & \multicolumn{1}{|c|}{ Least } & \multicolumn{1}{c|}{ Less } & \multicolumn{1}{c|}{ Moderate } & \multicolumn{1}{c|}{ High } & \multicolumn{1}{c|}{ Most } & Total \\
\hline Increasing Customer Pool & 2.78 & 8.33 & 22.22 & 33.33 & 30.56 & 97.22 \\
\hline Greater Profit Opportunity & 0.00 & 5.56 & 36.11 & 27.78 & 27.78 & 97.22 \\
\hline Risk Diversification & 19.44 & 11.11 & 33.33 & 13.89 & 13.89 & 91.67 \\
\hline Existence of NRBs & 2.78 & 11.11 & 19.44 & 19.44 & 30.56 & 83.33 \\
\hline Product Diversification & 0.00 & 8.33 & 30.56 & 25.00 & 16.67 & 80.56 \\
\hline Mature Domestic Market & 5.56 & 13.89 & 22.22 & 25.00 & 5.56 & 72.22 \\
\hline Increasing Brand Image & 2.78 & 0.00 & 2.78 & 8.33 & 5.56 & 19.44 \\
\hline Others & 2.78 & 0.00 & 0.00 & 5.56 & 11.11 & 19.44 \\
\hline
\end{tabular}

Source: Developed by authors based on survey data

Among the banks that already have international banking services and operations, 70\% expressed their willingness to expand more while $80 \%$ of the banks having no such activity yet said they would like to introduce such services or operations as shown by Figure-5 (a).

Figure 5(a): Want to introduce or expand?

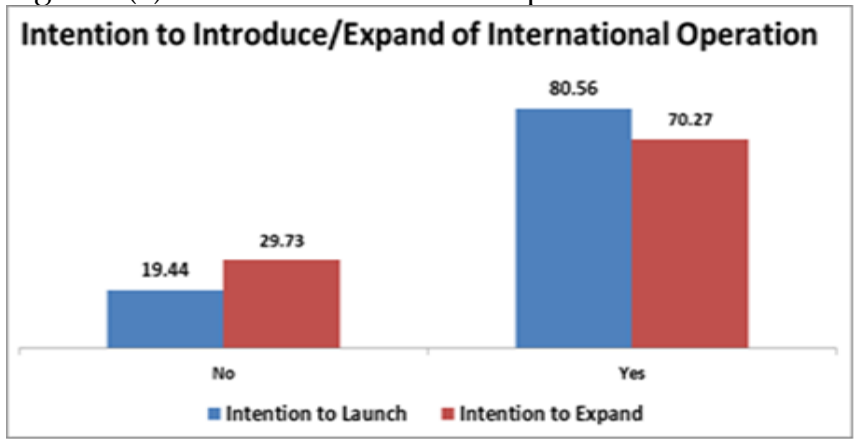

Figure 5(b): How Would You Introduce and Expand?

Choice of Mode for Internaitonal Introduce/Expansion

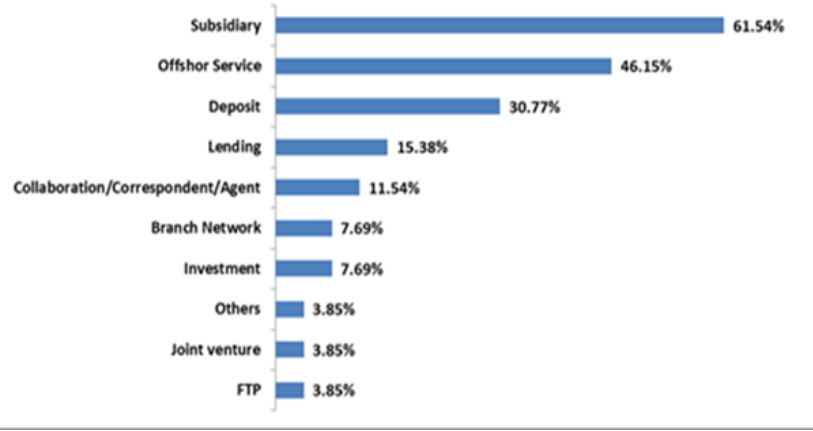

Source: Developed by authors based on survey data.

Interestingly, most banks (62\%) reported that they would like to start or expand with Subsidiary operations although this is the highest layer of internationalization as defined earlier and involves a larger amount of financial investment 
commitment and greater degree of risk. This can be seen in Figure-5 (b). A reasonably $46 \%$ banks are interested to introduce or expand on-going offshore services. A fair number of banks (45\%) are interested to go for cross-border lending and deposit activities but only $8 \%$ of the banks are interested in investing abroad. However, still some $20 \%$ are interested in collaborative approach and branch network as their choice of introducing newly or expanding further.

\section{Managerial Independence and Integration}

The banks having international operations (branches, subsidiary etc.) were asked about how much their foreign operations have managerial and operational independence.

Table 2: Degree of Independence of International Operations from Bangladesh Head Office

\begin{tabular}{|l|c|c|c|c|c|}
\hline & \multicolumn{3}{|c|}{$\begin{array}{c}\text { Degree of Independence } \\
\text { (Figures in \% Banks) }\end{array}$} & \\
\hline \multicolumn{1}{|c|}{ Independence for } & Least & Less & Moderate & High & Most \\
\hline Decision Making & 19.44 & 11.11 & 22.22 & 16.67 & 16.67 \\
\hline Command and Control & 19.44 & 11.11 & 22.22 & 16.67 & 16.67 \\
\hline Communication & 11.11 & 11.11 & 11.11 & 30.56 & 19.44 \\
\hline Employee Recruitment & 30.56 & 13.89 & 11.11 & 16.67 & 16.67 \\
\hline Product \& Service Delivery & 16.67 & 19.44 & 8.33 & 30.56 & 11.11 \\
\hline Increasing Scope of Operation & 13.89 & 13.89 & 25.00 & 8.33 & 16.67 \\
\hline Use of Fund Abroad & 13.89 & 22.22 & 11.11 & 5.56 & 5.56 \\
\hline Others & 0.00 & 0.00 & 0.00 & 0.00 & 2.78 \\
\hline
\end{tabular}

Source: Developed by authors based on survey data

Table 3: Degree of Integration of International Operations with Bangladesh Head Office

\begin{tabular}{|l|c|c|c|c|c|}
\hline & \multicolumn{5}{|c|}{$\begin{array}{c}\text { Degree of Integration } \\
\text { (Figures in \% Banks) }\end{array}$} \\
\hline Integration of & Least & Less & Moderate & High & Most \\
\hline Decision Making & 5.56 & 5.56 & 27.78 & 8.33 & 30.56 \\
\hline Command and Control & 2.78 & 5.56 & 11.11 & 30.56 & 25.00 \\
\hline Communication & 2.78 & 2.78 & 25.00 & 25.00 & 19.44 \\
\hline Employee Recruitment & 11.11 & 5.56 & 16.67 & 11.11 & 27.78 \\
\hline Product \& Service Delivery & 16.67 & 19.44 & 8.33 & 30.56 & 11.11 \\
\hline Increasing Scope of Operation & 13.89 & 13.89 & 25.00 & 8.33 & 16.67 \\
\hline Use of Fund Abroad & 13.89 & 22.22 & 11.11 & 5.56 & 5.56 \\
\hline Others & 0.00 & 0.00 & 0.00 & 0.00 & 2.78 \\
\hline
\end{tabular}

Source: Developed by authors based on survey data

Results suggest that most banks reported that they provided a fair degree of independence on decisionmaking, chain of command and control, communication, and product and service delivery. About $55 \%$ of the banks have rated the level of independence on these managerial issues as moderate to the highest level which indicates that banks are more open, decentralized and liberal approach to foreign operations. However, as banks reported, command and control, communication, and product and service delivery issues in foreign operations are highly integrated to their Head Offices since more than $50 \%$ of the banks rated the degree of integration to be high to the highest level (Table-3). However, both Table-2 and Table-3 show that with respect to employee recruitment, increasing scope of operation and utilization of fund abroad, most banks reported significant level of freedom enjoyed by the foreign operations however lesser integration is required with domestic operation or head-offices.

\section{Challenges of International Banking Operations}

A number of challenges have been reported which makes introducing and delivering international banking operation and services quite difficult, risky and costly. Differences in regulatory requirements and higher level of complexity in regulatory compliances are considered as the most challenging among all. Introducing and delivering international banking products and services through foreign operations always require double regulatory compliances both at home and abroad. Moreover, regulation in host country may be too high, complex and difficult to comply, and even so stringent that domestic legal preparations may not work at all in the host countries. Therefore, as Table- 4 shows, regulatory barrier and complexity has been rated as the highest of all challenges while about $70 \%$ banks rate this at higher to the highest level of challenge. In addition, lack of experience, expertise and knowhow also have been reported as one of the major challenges by more than $50 \%$ of the banks which is supported by lack of human resources being a major critical challenge of all as reported by $40 \%$ banks. However, about $50 \%$ of the banks rated differences in social and managerial cultural, higher competition and operational complexity as a moderate to high level of challenge placing at the second position of ranking among all challenges. Surprisingly, only $2.7 \%$ of the banks reported increased level of riskiness as a challenge for international banking operation abroad although research and theories suggest that it is one of the highly crucial factors that affect the decision to go international.

Table 4: Challenges of International Banking Operations

\begin{tabular}{|l|c|c|c|c|c|c|}
\hline & \multicolumn{5}{|c|}{$\begin{array}{c}\text { Degree of Severity } \\
\text { (Figures in \% Banks) }\end{array}$} \\
\hline Challenges & Least & Less & Moderate & More & Most & NO \\
\hline Lack of Experience & 5.41 & 13.51 & 16.22 & 24.32 & 32.43 & 5.41 \\
\hline Regulatory Complexity & 5.41 & 2.70 & 16.22 & 27.03 & 40.54 & 5.41 \\
\hline Higher Degree Competition & 10.81 & 13.51 & 37.84 & 29.73 & 5.41 & 0.00 \\
\hline Cultural Difference & 18.92 & 24.32 & 13.51 & 16.22 & 10.81 & 13.51 \\
\hline Operational Complexity & 13.51 & 5.41 & 29.73 & 16.22 & 18.92 & 13.51 \\
\hline Domestic Linkage & 10.81 & 16.22 & 24.32 & 18.92 & 10.81 & 16.22 \\
\hline Wining Marketing Strategy & 5.41 & 21.62 & 16.22 & 21.62 & 10.81 & 16.22 \\
\hline Lack of Human Resources & 2.70 & 10.81 & 18.92 & 21.62 & 24.32 & 13.51 \\
\hline Different Managerial Culture & 8.11 & 5.41 & 29.73 & 16.22 & 13.51 & 16.22 \\
\hline Increased Riskiness & 0.00 & 0.00 & 0.00 & 0.00 & 2.70 & 2.70 \\
\hline
\end{tabular}

Source: Developed by authors based on survey data

\section{Banks' Overall Policy/Opinion on International Banking}

A more generalized view was asked from the banks what they think about going international to state in few sentences. About $41 \%$ of the banks stated that it is good for the country since it would largely contribute to the economic development of Bangladesh while 14\% banks believe such activity would also ensure sustainable growth for banking sector. The idea of Banks' sustainable growth can be ensured by serving a diverse range of customers globally (as 27\% banks reported) as this would increase capability and expertise of the banks. However, more responses included expansion of operational activities, enhancing profit; brand image improvement and stockholder value increase were also found although a very small number of banks reported these. 
Figure 6: General Attitude or Policy Perspective on International Banking

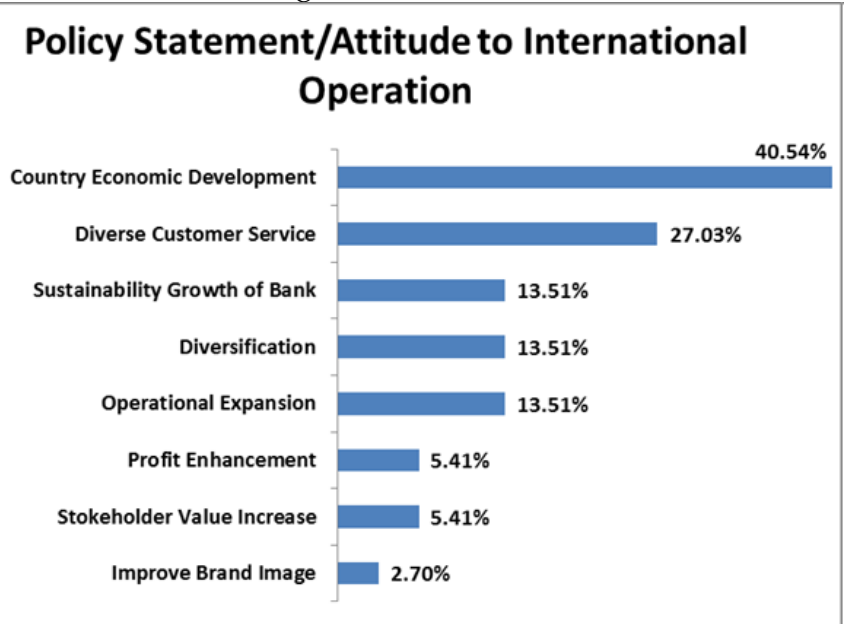

Source: Developed by authors based on survey data

\section{Should the Bangladeshi Banks Move Aggressively Outward Now?}

A more generalized question was asked from the banks whether they feel this is the right time for Bangladeshi Banking sector to move to international market with foreign operations. Many believe that Bangladeshi market for banks has neared to saturation and too many banks have already been playing, and many are struggling to keep the bottom line for survival as well as for growth. In this situation, $77 \%$ of the banks reported affirmatively and they advocated for designing internationally competitive business strategies, equipping with necessary preparations and moving towards the foreign market actively. About $19 \%$ of them said that going international would help Bangladeshi banks in building high global brand image and the opportunity to serve fast increasing NRB base in a number of diverse countries around the world. However, with respect to enhancing profit, competitiveness improvement, and international trade improvement, only $11 \%$ banks responded to each of these items affirmatively. It means that a small number of banks are basically hopeful about improvement in these areas going into the foreign market and starting foreign operation actively.

\section{Perceived Impact on Banking Practices}

Banks are divided on their opinion that internationalization has significant impact on domestic operation. In this study it is found that $27 \%$ banks are agreed up on this fact that internationalization has significant impact on domestic operation whereas $66 \%$ banks support this opinion strongly. Remaining 7\% banks stayed neutral. No bank was found who thought there is no impact of internationalization on domestic operation. Banks were also asked to provide their opinion on the possible impact of internationalization on profitability. The study shows there has been mixed opinions. About $32 \%$ banks agreed upon with this statement and $44 \%$ strongly supports that internationalization has impact on profitability. Some banks think there is no impact of internationalization on profitability and this percentage is $12 \%$. Among this portion $10 \%$ disagree with this statement and remaining $2 \%$ bank strongly thinks there is no impact of internationalization on profitability.

Figure 7(a): Perceived Impact on Domestic Operation

\section{IB has Significant Impact on Domestic Operation}

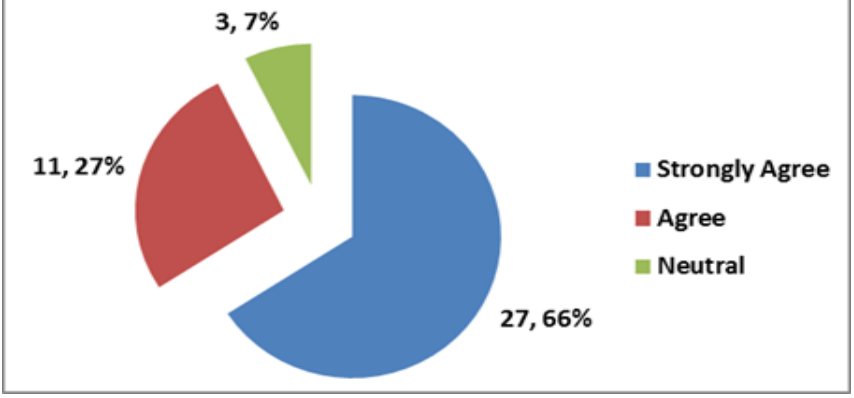

Figure 7(b): Perceived Impact on Profitability

\section{IB may Significantly Impact Profitability}

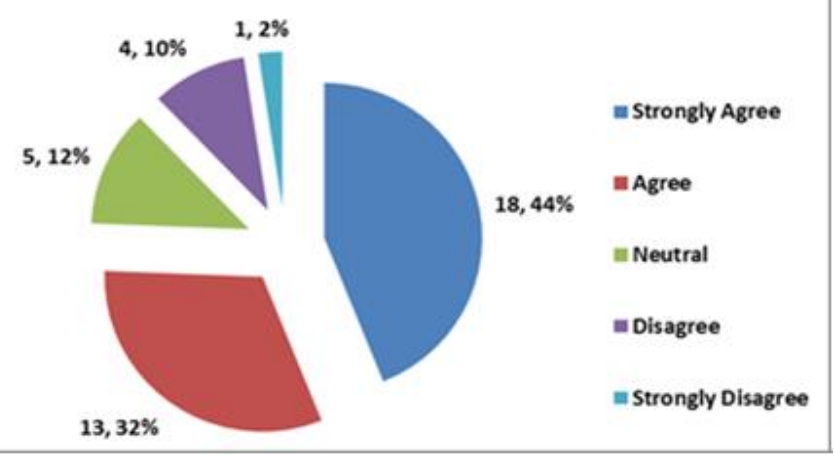

Source: Developed by authors based on survey data.

Table-5 shows the sources of such improvement on domestic operation. Most of the banks think that the major sources are operational excellence, profitability and brand image. However, around $41 \%$ of the banks consider profitability and brand image development as the best areas of advantages to be acquired through international banking activities.

Table 5: In What Areas IB Can Create Improvement of Domestic Banking?

\begin{tabular}{|l|c|c|c|c|c|c|}
\hline & \multicolumn{5}{|c|}{$\begin{array}{c}\text { Degree of Improvement } \\
\text { (Figures in \% Banks) }\end{array}$} & \\
\hline Sources of Improvement & Least & Less & Moderate & More & Most & Total \\
\hline Operational Excellence & 2.44 & 17.07 & 26.83 & 26.83 & 17.07 & 90.24 \\
\hline Profitability & 7.32 & 9.76 & 17.07 & 41.46 & 17.07 & 92.68 \\
\hline Brand Image & 0.00 & 2.44 & 17.07 & 31.71 & 41.46 & 92.68 \\
\hline Employment Generation & 0.00 & 0.00 & 2.44 & 0.00 & 0.00 & 2.44 \\
\hline Increase Foreign Trade & 0.00 & 0.00 & 2.44 & 2.44 & 0.00 & 4.88 \\
\hline Global Presence & 0.00 & 0.00 & 2.44 & 0.00 & 2.44 & 4.88 \\
\hline Diversification & 0.00 & 0.00 & 0.00 & 0.00 & 4.88 & 4.88 \\
\hline
\end{tabular}

Source: Developed by authors based on survey data. 


\section{FINDINGS AND CONCLUSION}

Findings are quite straight-forward and insightful. Most banks (about 90\%) have some forms of international products, services and operation among which a threefourth banks offer wholesale and money exchange services through their international windows. About half of the banks introduced international banking activities not much lately. Although highly it is cost-intensive (Buch et al., 2011), more than three-fourth banks in Bangladesh have already gone for setting-up 'Subsidiary' in foreign countries while although having offshore banking and foreign trade product is much cheaper forms, significantly less number of banks have done so. And interestingly, although the 7-layer expansion path of internationalization is supposed to have a downward curve, findings suggest that the frequencies of banks at every layer is scattered, and hence the trend curve shows upward slope. It means Bangladeshi banks do not follow the usual expansion path for internationalization in contrast to the hypothesized theoretical arguments. The opportunity to add new customer base, bigger business and profit volume, mature domestic market, and existence of NRBs have been found as the main incentives for internationalization. The findings on bigger market opportunities, increasing customer base, and profit expectations have been consistent with other literature (Hryckiewicz and Kowalewski, 2008; Rahman and Anwar, 2011; Amungo, 2014; and Yuliya and Adela, 2012). The findings on Non-Resident Bangladeshis (NRBs) is also consistent with other literature (see Canals, 1997) as banks drive to move to countries where most Bangladeshi migrate or work and send remittances to home. This can be termed as "Defensive Expansion" as banks are targeting only those who are moving out from Bangladesh (Lensink and Hermes, 2004). Despite some benefits, there are a number of managerial complexities in integration between domestic and foreign operation in terms of decision making, control, and communication while foreign operations enjoy higher degree of freedom in these issues. These findings are found to be new additions to the current literature.

Lack of experience, regulatory complexity and higher competition are the major challenges reported by the banks. These findings are also found to be consistent with others since preparedness on these issues is essential for achieving internationalization benefit (Porter, 1985; Cho, 1986). Despite, findings suggest that $60 \%$ banks want to introduce or expand their international banking activities, and very surprisingly 'Subsidiary' is the entry mode most banks consider although it is a highly cost-intensive and can create negative outcome on profitability (Buch et al., 2011). However, about half of the banks also chose offshore services and one third shows interest in depositing abroad which are relatively cheaper modes of internationalization. About $80 \%$ banks, having international activities, frequently organize both in-house and external training inside and outside Bangladesh to develop human resource expertise.
Most banks believe that spreading international banking worldwide would contribute positively to the economic growth of the nation. Three-fourth of the banks believes this is the high time for Bangladeshi banks to go international with substantial level of efforts and preparations. It is because they feel international banking operation would contribute to improvise their domestic operation as well the overall profitability coupled with diversification and brand building benefit. As findings suggest, Bangladeshi Banks are still defensively moving forward following Bangladeshi citizens worldwide. However, preparedness must take place from today for an aggressive wave of future internationalization. Although the research does not directly respond to government policy aspects, it is suggested that Bangladesh Bank - the central bank of Bangladesh must look into the rising trend and age of bank internationalization in Bangladesh. It should have a little watch over the cost-intensive international expansion of the banks so that banks can better manage such foreign operations. Moreover, due to globalization, the internationalization pace is expected to be faster in the coming days and hence Bangladesh Bank should begin to think and design appropriate policy framework and guidelines to facilitate a resilient bank internationalization wave. While doing so, the riskiness must be wellconsidered by the regulator and thus proper supervision must be placed so that banks do not internationalize heavily in an unbalanced manner and struggle during international financial crisis.

\section{REFERENCES}

Amungo, E. (2014), "The internationalization of Nigerian banks: Influences and entry mode choices", Unpublished DBA thesis, Heriot Watt University, Edinburgh, Scotland, UK, available

http://www.ros.hw.ac.uk/bitstream/handle/10399/2735/ AmungoE_0414_ebs.pdf;jsessionid=2EE44318982D932CB38 7686AF5FD3DB5? sequence=1. (Accessed 03 July 2015).

Andersen, O. (1993), "On the internationalization process of firms: A critical analysis of firms", Journal of International Business Studies, Vol. 24, No. 2, pp. 209-231.

Antonsson, E. and Arrhenius, A. (2011), "Evaluation of banking internationalization-A case study of Nordea in Poland and SEB in Germany", Unpublished master's thesis, Jonkoping International Business School, Jonkoping University, available at http://hj.divaportal.org/smash/get/diva2:420281/FULLTEXT01.pdf. (accessed 06 July 2015).

Berger, A. N., DeYoung, R., Genay, H. and Udell, G. F. (2000), "Globalization of financial institutions: Evidence from cross-border banking performance", Brookings -Wharton papers on financial services, no 99-25, DOI: 10.2139/ssrn.203509.

Berger, A. N., Ghoul, S. E., Geudhami, O. and Roman, R. A. (2015), "Internationalization and bank risk", NC State University, available at http:/ /www.poole.ncsu.edu/gradecon/ (accessed 07 June 2015).

Brimmer, A. and Dahl, F. (1975), "Growth of American international banking: Implications for public policy", Journal of Finance, Vol. 30, No. 2, pp. 341-363. 
Buch, C. M., Driscoll, J. C. and Ostergaard, C. (2010), "Crossborder diversification in bank asset portfolios", International Finance, Vol. 13, No. 1, pp. 79-108.

Buch, C., Koch, C. T. and Katter, M. (2011), "Do banks benefit from internationalization? Revisiting the market power-risk nexus", Review of Finance, Oxford University Press.

Canals, J. (1997), Universal Banking:International Comparisons and Theoretical Perspective, Oxford University Press, Oxford.

Cerutti, E., Ariccia, G. D. and Peria, M. S. M. (2007), “How banks go abroad: Branches or subsidiaries?", Journal of Banking \& Finance, Vol. 31, No. 6, pp. 1669-1692.

Cho, K. R. (1986), "Determinants of multinational banks", Management International Review, Vol. 26, No. 1, pp. 10-23.

Cunha, S. and Boehe, D. M. (2008), "Why do banks internationalize? The distinctive strategy of a brazilian retail bank Encontra de Anpad", no. 32, September, National Association of Post Graduate and Research in Administration, Brazil.

Goldberg, L. G. and Saunders, A. (1981), "The determinants of foreign banking activity in the United States", Journal of Banking and Finance, Vol. 5, No. 1, pp. 17-32.

Haque, S. (2013), "The performance analysis of private conventional banks: A case study of Bangladesh", IOSR Journal of Business and Management (IOSR-JBM), Vol. 12, No. 1, pp. 19-25.

Hollensen, S. (2008), Essential of Global Marketing, Harlow: Prentice Hall, Pearson Education Limited.

Hryckiewicz, A. and Kowalewski, O. (2008), "Economic determinants and entry modes of foreign banks into Central Europe", Wharton Financial Institutions working paper no. 08-08, Warsaw School of Economics, Poland.

Islam, M. M. and Alam, A. (2010), “Top five first generation banks-A comparative analysis", available at http:/ / www.bracepl.com. (Accessed 11 June 2015).

Johanson, J. and Wiedersheim-Paul, F. (1975), "The internationalization of the firm - Four Swedish cases", Journal of Management Studies, Vol. 12, No. 3, pp. 305-22.

Jones, G. (1993). "British multinational banking strategies over time", in Cox, H., Clegg J. and Ietto-Gillies, G. (Eds.), the growth of global business, London and New York: Routledge, pp. 38-61.

Khoury, S. J. (1998), "Foreign banks in the United States: Entry strategies and operations", Advances in International Banking and Finance, Vol 3, pp.152-175.

Kobrin, S. J. (1991), "An empirical analysis of the determinants of global integration", Strategic Management Journal, Vol. 12, No. 1, pp. 17-37.

Lensink, R. and Hermes, N. (2004), "The short-term effects of foreign bank entry on domestic bank behaviour: Does economic development matter?" Journal of Banking and Finance, Vol. 28, No. 3, pp. 553-568.
Li, J. and Guisinger, S. (1992), “The globalization of service multinationals in the Triad Regions: Japan, Western Europe and North America", Journal of International Business Studies, Vol. 23, No. 4, pp. 675-696.

Mutinelli, M. and Piscitello, L. (2001), "Foreign direct investment in the banking sector: The case of Italian banks in the $90 \mathrm{~s}^{\prime \prime}$, International Business Review, Vol. 10, No. 6, pp. 661-685.

Porter, M. E. (1985), The competitive advantage: Creating and sustaining superior performance, New York: Free Press.

Rahman, I. B. A. and Anuar, M. R. (2011), "What motivates Malaysian banks to go international? A case of Islamic banking products", paper presented at 8th International Conference on Islamic Economics and Finance, Qatar National Convention Center, Doha, Qatar.

Rubaeva, M. (2010), "Internationalization of western retail company eastwards: Metro Group case", Unpublished Master's thesis, The Aarhus School of Business.

Slager, A. (2005), "Internationalization of banks: Strategic patterns and performances", SUERF - The European money and finance forum, Vienna, available at http:/ /www.suerf.org/docx/s_2ba596643cbbbc2031822418 1fa46b28_957_suerf.pdf (accessed 22 July 2015).

Smith, R. C. \& Walter, I. (1997), Global banking, New York: Oxford University Press.

Sullivan, D. (1994), "Measuring the degree of internationalization of a firm", Journal of International Business Studies, Vol. 25, No. 2, pp. 325-342.

Tripe, D. (2003), "The international expansion of Australian banks", in Lonnborg, M.; Olsson, M.; Rafferty, M. and Nalson, I. (Eds.), Money and Finance in Transition, Huddinge, Sweden: Sodertornshogskola, pp. 155-180.

Trivedi, A. K. (2012), "International and multinational banking", in Trivedi, A. K., Patwardhan, A. K. and Pawsee, A. R. (Eds.), International banking operation, Macmillan Publishers India Limited, Indian Institute of Banking and Finance, Mumbai, India, pp. 4-15.

Tschoegl, A. E. (2001), "The international expansion of Singapore's largest banks", The Wharton Financial Institutions Center, University of Pennsylvania, available at http:/ / fic.wharton.upenn.edu/fic/ (accessed 07 June 2015).

Williams, R 2015a, "Multicollinearity:, University of Notre Dame, January 13, available at https://www3.nd.edu/ rwilliam/stats2/111.pdf (accessed 22 June 2015)

Williams, R 2015b, "Heteroskedasticity", University of Notre Dame, January 30, available at http:/ / www3.nd.edu/ rwilliam/ (accessed 22 June 2015).

Yuliya, M. \& Adela, N. (2012), "Internationalization of service firms- Case study of Swedbank and SEB bank", Unpublishedmaster's dissertation, Halmstad University, Sweden.

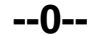




\section{SoCIAL SCIENCE RESEARCH NETWORK}

2171 Monroe Avenue, Suite 203, Rochester, NY 14618, USA

$$
\text { http://www.ssrn.com/en/ }
$$

AJTP Link: http://www.ssrn.com/link/American-Journal-Trade-Policy.html 